\title{
Reviewing of Teachers' Professional Competencies for Inclusive Education
}

\author{
Şule Firat Durdukoca ${ }^{1}$ \\ ${ }^{1}$ Department of Special Education, Dede Korkut Faculty of Education, Kafkas Univercity, Kars, Turkey \\ Correspondence: Şule Firat Durdukoca, Department of Special Education, Dede Korkut Faculty of Education, \\ Kafkas Univercity, Central Campus, Combined Road, 36100, Kars, Turkey.
}

Received: March 15, 2021

doi:10.5539/ies.v14n10p1
Accepted: June 21, $2021 \quad$ Online Published: September 8, 2021

URL: https://doi.org/10.5539/ies.v14n10p1

\begin{abstract}
This study aims to review the professional competencies of classroom teachers for inclusive education according to different variables, to obtain information about teachers' in-class practices and to evaluate their perceptions of professional competencies in depth. The research is a mixed-method study and carried out using the trilinguation. The quantitative data were collected from 203 classroom teachers and the qualitative data from 58 teachers. The data were collected using the "Professional Competency Scale for Teachers on Inclusion" and a semi-structured interview form. The validity and reliability studies of the scale were repeated. The research determined that the professional competencies of participating teachers regarding inclusive education are at a high level, professional competency does not differ according to the variables of gender and seniority, and the professional competency levels of teachers regarding inclusive education differ according to the number of students affected by disability. Besides, it was determined that participant teachers carried out similar classroom practices for their students affected by disability and generally, had a perception that not every student could learn.
\end{abstract}

Keywords: inclusive education, professional competency, special need

\section{Introduction}

Having special needs is one of the essential variables affecting all aspects of an individual's life. Being diagnosed as "the person affected by disability" within the scope of special needs is a sign that generally, difficult living conditions await the individual. Because persons with this diagnosis experience various problems such as long-term physical, mental or emotional disorders, and due to these problems, they cannot fully and equally participate in society like others (United Nations, 2007). These persons must go through an education-training process that will make it easier for them to solve the problems they will encounter in life and to gain the ability to live independently. In this process, learners' presence in general education classes (Diken \& Batu, 2013), which is considered to be the least restrictive environment in special education, can help them to develop their awareness of problems, seek solutions, problem solving, academic, social and emotional characteristics.

Inclusive education, which can be defined as including students, affected by disability in general education classes, "helps children with special needs to live a more community-based life at school age" (Stromstad, Nes, \& Skogen, 2004). Inclusive education, which is essentially a right to education, not a privilege, to learners affected by inadequacy; provides benefits such as making friends, increasing the achievements of the curriculum, developing high-level skills such as generalization, communicating with the school staff, increasing the willingness of their parents to cooperate with the school, ensuring that he and his family are more integrated into society. Inclusive education is known to provide benefits such as perceiving and accepting individual differences, respecting all people, empathizing, reducing prejudices, and achieving better academic success also for students with normal development (Organisation for Economic Cooperation and Development, [OECD], 1999; World Health Organization [WHO], 2011).

Access levels of learners to the benefits listed above from inclusive education that promotes quality and equal education for all without exclusion (Mag, Sinfield, \& Burns, 2017), related to enormous diversity seen in the quantity and quality of students affected by disability and whether teachers have the professional competency to continue their educational activities with this diversity.

World Report on Disability states that the number of children aged 0-14 affected by disability varies between 
93-150 million globally, and it is estimated that $15 \%$ to $20 \%$ of learners will need special education at some stage of their school life, although the classification of learners affected by disability and therefore in need of special education differs from country to country, the integration of these learners in inclusive education has become a widespread desirable situation in terms of equality and human rights (WHO, 2011). Based on this information, we can comment that there is an increase in the number and variety of students involved in inclusive education almost every year. For instance, in Turkey from the 2001-2002 academic year to the 2018-2019 academic year, the number of disabled students who participated in formal education has an increase by approximately 7.5 times and $74.1 \%$ of total disabled students were in inclusive education, in the 2018-2019 academic year (Ministry of Family, Labour and Social Services, 2020). Ministry of National Education (MNE) determined the disability types of students who will benefit from inclusive education as; persons with mental, hearing, visual, physical disabilities, autistic persons, persons with language and speech difficulties, special learning difficulties, attention deficit and hyperactivity disorders (2010). Therefore, there are students diagnosed with these types of disability in the classrooms. In this case, expectations from teachers also increase.

Experts studying inclusive education now argue that teachers should be aware of a range of broad principles, such as knowing that there is diversity in the classroom, that individual differences are more prominent, and that they should pay more attention to students with special needs (Mintz, 2019). Studies have shown that the success of inclusive education depends on the willingness of educators (Nina, Silva \& Pontes, 2020), professional competency (Moeller \& Ishii-Jordan, 1996; Paneque \& Barbetta, 2006; Sharma, Forlin, \& Loreman, 2011), and especially teachers' professional competencies are the focal point of inclusive education (Kristiana \& Hendriani, 2018). Professional competence in inclusive education can be defined as "teachers' evaluating their competencies for teaching in an integrated classroom consisting of normal and students with special needs" (Andrews \& Lupart, 2020; Loreman, Sharma, \& Forlin, 2013). In this context, a teacher with high professional competency leads to an increase in the success and positive behaviour examples of students affected by disability due to their positive attitude towards classroom management and inclusive education practices (Ahsan, Sharma, \& Deppeler, 2012), whereas a teacher with a low perception of competency may behave in an attitude of reluctance to include students affected by disability and refuse inclusive education (Lee et al., 2014). Therefore, teachers' professional competencies regarding inclusive education have been seen as an issue worth examining.

\subsection{Purpose of the Study}

The main purpose of this study is to examine teachers' professional competencies regarding inclusive education according to various variables, to obtain information about in-class practices and to evaluate their perceptions of professional competencies in depth. Besides, it is expected that the results obtained from this study will provide information about the teacher-induced factors that affect the success of inclusive education and will shed light on future studies on this subject. For this purpose, answers to the following questions are sought:

- How are the teachers' professional competencies regarding inclusive education? Does this competency differ according to the gender, seniority of teachers, and the number of students affected by the total disability in their classes?

- How do teachers design lesson plans for their students affected by disability, organize the learning-teaching environment and process, and assessment-evaluation process?

- What are the teachers' perceptions about "each student can learn" notion?

\section{Method}

\subsection{Model and Study Group}

The research is a mixed-method study and was carried out using the trilinguation. The working group consists of classroom teachers who have at least 1 inclusion student in their classrooms and want to participate in the research voluntarily. Quantitative data were collected from 203 classroom teachers. $56 \%$ of the teachers $(\mathrm{n}=$ 113) are female, the tenure of $31 \%(n=63)$ varies between $11-15$ years. $32 \%$ of the teachers $(n=64)$ received training on inclusion practices, $88 \%(\mathrm{n}=56)$ stated that this education they received was not sufficient. Until the spring semester of the 2019-2020 academic year, when the study was conducted, the total number of inclusion students in the teachers' classroom is a minimum of 2 and a maximum of 19. Qualitative data were collected with the participation of 58 teachers that were determined with maximum diversity among the teachers participating in the quantitative dimension of the study, according to their; seniority degrees (1-5 years $\mathrm{n}=11$, 6-10 years $n=13,11-15$ years $n=18,16$ years and above $n=16$ ), places of duty (provincial centre $n=24$, district centre $n=34$ ), education status related to inclusion ( $n=21$ receiving an education), the total number of inclusive students in their classes $\left(\mathrm{n}_{\min .}=4, \mathrm{n}_{\max }=15\right)$. 


\subsection{Data Collection Tool and Analysis}

The data were collected using the "Professional Competency Scale for Teachers on Inclusion" and a semi-structured interview form developed by the researcher. The scale was prepared by Karaca and Sar1 (2018), but the validity study was repeated with the data collected from 212 classroom teachers who were not included in the study group because the Confirmatory Factor Analysis (CFA) was not carried out and some of the items were not suitable for the study group of this study. As a result of the Exploratory Factor Analysis (EFA), it was determined that the Kaiser-Meyer-Olkin measurement result of the data set was .67, and Bartlett's Sphericity Chi-Square test result was significant $(\mathrm{p}<.05)$. As a result of principal component analysis and EFA performed with Varimax method, it was determined that the scale consisted of 17 items in 5 factors and these items explained $64 \%$ of the total variance. The Alpha reliability coefficients of the scale were determined to be $.80, .70, .83, .77$, and .82 based on the factor, respectively, and the Alpha coefficient of the scale sum was .77. It was determined that the item in the scale could distinguish the lower and upper $27 \%$ groups significantly $(\mathrm{p}<.05)$ from each other, thus the internal consistency reliability of the scale was tested.

Using the LISREL program, we started the CFA analysis of the scale with 5 factors and 17 items, and firstly, $t$ values for the items were examined. It was determined that the $t$ values of the 14th and 32nd items were not meaningful, the Standard Solution values for these items were lower than .30, and the error variances were greater than .90 . However, as these items were determined to be significant in explaining the theoretical structure of the scale, it was decided to keep them in the analysis. To determine that the 5 -factor structure of the model was verified in CFA, the fit indices were examined and the values obtained are presented in Table 1.

Table 1. Fit indices of the scale and limit values of indices

\begin{tabular}{ccc}
\hline Fit Measure & Limit Values & Model \\
\hline$\chi 2 / s d$ & $\leq 5$ & 1.3 \\
RMSEA & $\leq 0.10$ & .03 \\
NFI & $0-1$ & .87 \\
NNFI & $0-1$ & .95 \\
CFI & $0-1$ & .96 \\
GFI & $0-1$ & .93 \\
AGFI & $0-1$ & .90 \\
\hline
\end{tabular}

Note. $\chi 2 / \mathrm{sd}=$ Chi Square/Freedom Degree, RMSEA= Root Mean Squared Error of Approximation; NFI=Normed Fit Index, NNFI=Non-Normed Fit Index, CFI=Comparative Fit Index, GFI=Goodness-of-Fit Index, AGFI=Adjusted Goodness-of-Fit Index. References for limit values: (Anderson \& Gerbing, 1984; Bollen, 1989; Jöreskog \& Sörbom, 1993; Marsh, Balla, \& McDonald, 1988)

According to Table 1, it can be said that the 5-factor structure of the scale is confirmed. However, when the modification indices were examined, it was seen that there was a relationship between the error variances of the 17th and 15th items under the same factor, and it was decided to modify the tested factor structure to better fit the data. As a result of repeated CFA; It was determined that $\chi 2 / \mathrm{sd}$ ratio was 1.06 , RMSEA value was .02 , NFI, NNFI, CFI, GFI, AGFI values were respectively $.90, .99, .99, .94, .91$, and the 5 -factor structure of the scale was confirmed.

Factors, following the original of the scale, was named as; Teaching Methods and Techniques $\left(\mathrm{n}_{\text {item number (in) }}=3\right.$ ), Individualized Education Program $\left(\mathrm{n}_{\mathrm{in}}=3\right)$, Diagnosis and Assessment $\left(\mathrm{n}_{\mathrm{in}}=4\right)$, Tasks and Responsibilities $\left(\mathrm{n}_{\mathrm{in}}=4\right)$, Family Education/Collaboration $\left(\mathrm{n}_{\mathrm{in}}=3\right)$. In the assessment of the average scores of the data collected through the "Professional Competency Scale for Teachers on Inclusion" which is a 5-point Likert-type measurement tool ranging from "I am very sufficient" to "very inadequate"; values of 1-1.80 "I am very insufficient", 1.81-2.60 "I am insufficient", 2.61-3.40 "I am partially sufficient", 3.41-4.20 "I am sufficient", 4.21-5.00 "I am very sufficient" were taken as criteria.

Before the semi-structured interview form was developed, the General Competencies of the Teaching Profession (MNE, 2017) were examined and 5 competency indicators expressing individual differences which requiring adaptation of the lesson plans for students with special needs and various elements of the curriculum were determined and converted into a question format and included in the interview form. The suitability of the questions to the purpose of the research and whether they provided the data on the subject to be researched were evaluated by 1 special education expert and 2 special education teachers, and the interview form whose validity 
was found to be sufficient was finalized. The teachers were informed about the purpose of the research, its confidentiality and the willingness to participate, and they were asked to write their opinions about each question in the form. The questions in the interview form are as follows: For your students who are affected by disability; (1) How do you prepare your plans? (2) How do you organize the learning environment? (3) How do you organize the teaching-learning process? (4) How do you organize the measurement-evaluation process? (5) Do you think every student can learn? The responses of the participants to each question were analyzed with the content analysis technique carried out separately by the researcher and an expert on inclusive education and content analysis. During the analysis phase, a consensus was achieved for the categories/codes created by the researchers in line with the participants' opinions. The level of reliability was determined for the categories created for each sub-problem. In the calculation made using the reliability calculation formula developed by Miles \& Huberman (1994), it was determined that the reliability level average was .91. To increase the validity of the study, direct quotations from the opinions of the participants were included in the interpretation of the findings.

\section{Results}

Descriptive analysis results for teachers' professional competencies regarding inclusive education are presented in Table 2.

Table 2. Teachers' professional competency levels regarding inclusive education

\begin{tabular}{ccccc}
\hline Scale sub-dimensions & Min. & Max. & $\bar{X}$ & SS \\
\hline TMT & 12 & 15 & 14.36 & .91 \\
IEP & 6 & 15 & 12.34 & 1.82 \\
DA & 5 & 20 & 12.15 & 2.52 \\
DR & 7 & 15 & 13.84 & 1.61 \\
FE/C & 7 & 15 & 10.29 & 1.51 \\
\hline
\end{tabular}

Note. TMT $=$ Teaching Methods and Techniques, IEP $=$ Individualized Education Plan, DA= Diagnosis and Assessment, $\mathrm{DR}=$ Duties and Responsibilities, $\mathrm{FE} / \mathrm{C}=$ Family Education/Collaboration.

Table 2 shows that teachers have the highest professional competency $(\bar{X}=4.78)$ in the TMT sub-dimension of the scale and the lowest professional competency $(\bar{X}=3.03)$ in the DA sub-dimension.

Table 3 shows the results of the t-test analysis performed to determine the differentiation of teachers' professional competencies in inclusive education according to their gender.

Table 3. Professional competency levels of teachers regarding inclusive education by gender

\begin{tabular}{|c|c|c|c|c|c|c|c|c|c|}
\hline \multirow[t]{2}{*}{ Scale sub-dimensions } & \multicolumn{2}{|c|}{ Female $(\mathrm{n}=113)$} & \multicolumn{2}{|c|}{ Male $(n=90)$} & \multirow[b]{2}{*}{ sd } & \multirow[b]{2}{*}{$\mathrm{t}$} & \multirow[b]{2}{*}{$\mathrm{p}$} & \multicolumn{2}{|c|}{$\begin{array}{c}\text { Levene test } \\
\text { results }\end{array}$} \\
\hline & $\bar{X}$ & ss & $\bar{X}$ & ss & & & & $\mathrm{F}$ & $\mathrm{p}$ \\
\hline TMT & 14.32 & .92 & 14.42 & .89 & 201 & -.74 & .46 & .17 & .69 \\
\hline IEP & 12.29 & 1.83 & 12.41 & 1.81 & 201 & -.46 & .64 & .13 & .72 \\
\hline DA & 12.46 & 2.63 & 11.76 & 2.34 & 201 & 1.95 & .052 & .70 & .40 \\
\hline DR & 13.90 & 1.55 & 13.77 & 1.68 & 201 & .54 & .58 & 1.87 & .17 \\
\hline $\mathrm{FE} / \mathrm{C}$ & 10.40 & 1.60 & 10.14 & 1.40 & 201 & 1.22 & .22 & 2.51 & .11 \\
\hline
\end{tabular}

When Table 3 is examined, it is seen that the professional competencies of the participant teachers regarding inclusive education do not differ significantly in all scale sub-dimensions by gender $(p>.05)$.

In Table 4 below, the analysis results of the Kruskal Wallis test conducted to determine the differentiation of the participant teachers' professional competencies regarding inclusive education according to their years of service are included. 
Table 4. Professional competency levels of teachers regarding inclusive education by seniority

\begin{tabular}{|c|c|c|c|c|c|c|}
\hline Scale sub-dimensions & Seniority & $\mathrm{n}$ & Mean rank & $\chi^{2}$ & sd & $\mathrm{p}$ \\
\hline \multirow{4}{*}{ TMT } & $1-5$ year(s) & 36 & 96.75 & \multirow{4}{*}{1.48} & \multirow{4}{*}{3} & \multirow{4}{*}{.69} \\
\hline & $6-10$ years & 43 & 103.42 & & & \\
\hline & $11-15$ years & 64 & 107.61 & & & \\
\hline & 16 years \&more & 60 & 98.15 & & & \\
\hline \multirow{4}{*}{ IEP } & $1-5$ year(s) & 36 & 98.61 & \multirow{4}{*}{.35} & \multirow{4}{*}{3} & \multirow{4}{*}{.95} \\
\hline & $6-10$ years & 43 & 103.67 & & & \\
\hline & $11-15$ years & 64 & 100.23 & & & \\
\hline & 16 years \&more & 60 & 104.73 & & & \\
\hline \multirow{4}{*}{ DA } & $1-5$ year(s) & 36 & 94.36 & \multirow{4}{*}{2.30} & \multirow{4}{*}{3} & \multirow{4}{*}{.51} \\
\hline & $6-10$ years & 43 & 96.10 & & & \\
\hline & $11-15$ years & 64 & 100.09 & & & \\
\hline & 16 years \&more & 60 & 102.18 & & & \\
\hline \multirow{4}{*}{ DR } & $1-5$ year(s) & 36 & 90.65 & \multirow{4}{*}{4.16} & \multirow{4}{*}{3} & \multirow{4}{*}{.25} \\
\hline & $6-10$ years & 43 & 107.74 & & & \\
\hline & $11-15$ years & 64 & 110.14 & & & \\
\hline & 16 years \&more & 60 & 96.01 & & & \\
\hline \multirow{4}{*}{$\mathrm{FE} / \mathrm{C}$} & $1-5$ year(s) & 36 & 82.65 & \multirow{4}{*}{5.14} & \multirow{4}{*}{3} & \multirow{4}{*}{.16} \\
\hline & $6-10$ years & 43 & 109.02 & & & \\
\hline & $11-15$ years & 64 & 105.59 & & & \\
\hline & 16 years \&more & 60 & 104.75 & & & \\
\hline
\end{tabular}

Table 4 indicates that the professional competencies of the participant teachers regarding inclusive education do not differ significantly according to their professional seniority ( $\mathrm{p}>.05)$.

In Table 5, Anova test results are presented to determine the differentiation status of teachers' professional competencies regarding inclusive education according to the total number of students affected by the disability in their classrooms.

Table 5. Professional competency levels of teachers regarding inclusive education according to the number of students affected by disability

\begin{tabular}{|c|c|c|c|c|c|c|}
\hline $\begin{array}{c}\text { Scale } \\
\text { sub-dimensions }\end{array}$ & Reason of Variance & Sum of Squares. & sd & Mean of Squares. & $\mathrm{f}$ & $\mathrm{p}$ \\
\hline \multirow{3}{*}{ TMT } & Between groups & 2.61 & 3 & .87 & \multirow{3}{*}{1.051} & \multirow{3}{*}{.37} \\
\hline & Within groups & 164.68 & 199 & .82 & & \\
\hline & Sum & 167.29 & 202 & & & \\
\hline \multirow{3}{*}{ IEP } & Between groups & 8.40 & 3 & 2.80 & \multirow{3}{*}{.84} & \multirow{3}{*}{.47} \\
\hline & Within groups & 661.46 & 199 & 3.32 & & \\
\hline & Sum & 669.86 & 202 & & & \\
\hline \multirow{3}{*}{ DA } & Between groups & 32.78 & 3 & 10.92 & \multirow{3}{*}{1.72} & \multirow{3}{*}{.16} \\
\hline & Within groups & 1257.48 & 199 & 6.31 & & \\
\hline & Sum & 1290.26 & 202 & & & \\
\hline \multirow{3}{*}{ DR } & Between groups & 10,05 & 3 & 3.35 & \multirow{3}{*}{1.29} & \multirow{3}{*}{.27} \\
\hline & Within groups & 514.21 & 199 & 2.58 & & \\
\hline & Sum & 524.26 & 202 & & & \\
\hline \multirow{3}{*}{$\mathrm{FE} / \mathrm{C}$} & Between groups & 19.47 & 3 & 6.49 & \multirow{3}{*}{2.89} & \multirow{3}{*}{$.04 *$} \\
\hline & Within groups & 446.37 & 199 & 2.24 & & \\
\hline & Sum & 465.85 & 202 & & & \\
\hline
\end{tabular}

*p<.05.

According to Table 5, the professional competency levels of the participating teachers in inclusive education according to the total number of students affected by the inadequacy in their classes within the service processes 
show a significant difference in the FE/C sub-dimension of the scale $(U=128.50, p<.05)$. According to the results of the Mann Whitney U test, the professional competency levels of teachers who have a total of 1-5 student(s) with special needs in their class during their service are higher than the competencies of teachers with a total of 16 or more special needs students in their $\operatorname{class}\left(\bar{X}_{1-5}\right.$ student(s) $\left.=34.75, \bar{X}_{16 \text { and more students }}=20.56\right)$. Similarly, teachers with a total of 1-5 special needs students in their class have higher levels of professional competency in inclusive education than teachers with a total of 6-10 special needs students in their class $\left(\bar{X}_{1-5}{ }_{\text {student(s) }}=95.74, \bar{X}_{6-10}\right.$ students $=72.07$ ).

The opinions of the participating teachers about how they prepared their teaching plans for their students affected by disability are presented in Table 6 together with the frequency values.

Table 6. Opinions on teaching planning for students affected by disability

\begin{tabular}{|c|c|c|}
\hline Categories & Codes & $\mathrm{f}$ \\
\hline \multirow{5}{*}{$\begin{array}{l}\text { Planning according to the disability type } \\
\text { of the student }\end{array}$} & Designing a teaching plan suitable for students' readiness levels & 46 \\
\hline & Adapting the activities according to the disability type of student & 34 \\
\hline & Designing new activities according to type of disability & 12 \\
\hline & Differentiating teaching methods and techniques & 11 \\
\hline & Differentiation of criteria in measurement and evaluation & 8 \\
\hline \multirow{2}{*}{$\begin{array}{c}\text { Planning according to the purpose of } \\
\text { inclusive education }\end{array}$} & Designing acquisitions/activities to improve life skills & 24 \\
\hline & Giving additional time in events & 19 \\
\hline \multirow{2}{*}{ Other } & Designing a curriculum according to student's school attendance & 1 \\
\hline & Designing plans with low-cost homework & 1 \\
\hline
\end{tabular}

Table 6 shows that the majority of teachers participating in the qualitative dimension of the study designed their teaching plans by taking into account the disability type of their students. 46 participant teachers stated that while planning the teaching-learning process, they primarily consider the level of readiness of their students, who are affected by disability. 11 participant teachers stated that their students differentiated the teaching methods and techniques in the teaching-learning process of the course according to the type of disability, and that they designed their lesson plans to apply some teaching techniques used in special education. For example, Teacher (T) 12 explained their view as "Student's readiness and type of disability are very important. First of all, I consider readiness, because, let's say, the student is visually disabled but will not be able to learn whatever activity I do if he/she is not ready for the subject to be covered today. The type of disability is also important. If possible, I adapt the activity on that day according to the type of disability... ".

In "Planning According to The Purpose of Inclusive Education" category, most of the teachers(n=24) stated that they designed plans for the implementation of the acquisitions/activities that would enable their students with special needs in the teaching-learning process to gain the knowledge and skills they could use in daily life. On the other hand, 9 participating teachers stated that they adapted the duration of the activities in the teaching-learning process according to the current performance of their students with special needs, they generally increased the duration of the activities for these students, and they also emphasized this additional time in their plans. T36 from the teachers stated his/her opinion as "... For example, an autistic student does not need to know how to connect an electrical circuit in parallel or in series in science class, but he needs to know what needs to be done to avoid being caught in an electric current... I always extend the duration of the activities, although it varies according to the type of the student's disability. I will add at least an extra 10-15 minutes... ".

In Table 7, teachers' opinions about the learning environment, teaching-learning process and measurement-evaluation process arrangements for their students affected by disability are presented. 
Table 7. Learning environment, teaching-learning and measurement-evaluation process arrangements for students affected by disability

\begin{tabular}{|c|c|c|c|}
\hline Arrangement Field & Categories & Codes & $\mathrm{f}$ \\
\hline \multirow{3}{*}{$\begin{array}{l}\text { Learning environment } \\
\text { arrangements }\end{array}$} & \multirow{3}{*}{$\begin{array}{c}\text { Adaptation in the physical layout of } \\
\text { the classroom }\end{array}$} & Changing the seating plan & 37 \\
\hline & & Stimulus reduction & 18 \\
\hline & & Lighting & 3 \\
\hline \multirow{7}{*}{$\begin{array}{c}\text { Teaching-learning process } \\
\text { arrangements }\end{array}$} & $\begin{array}{c}\text { Arranging teaching methods \& } \\
\text { techniques }\end{array}$ & Applying special teaching methods and techniques & 11 \\
\hline & \multirow{4}{*}{$\begin{array}{c}\text { Organizing teaching materials \& } \\
\text { tools }\end{array}$} & Using written materials & 34 \\
\hline & & Using visual materials & 18 \\
\hline & & Using tactile materials & 6 \\
\hline & & Using real objects & 2 \\
\hline & \multirow{2}{*}{ Arranging reinforcers } & Using fixed reinforcer & 16 \\
\hline & & Using symbol reinforcer & 11 \\
\hline \multirow{4}{*}{$\begin{array}{l}\text { Measurement-Evaluation } \\
\text { process arrangements }\end{array}$} & \multirow{3}{*}{$\begin{array}{c}\text { Arranging stage defining summative } \\
\text { evaluation questions }\end{array}$} & Evaluating performance in the classroom & 46 \\
\hline & & Assessment in the same way as other students & 41 \\
\hline & & Decreasing the number of questions & 13 \\
\hline & Arranging exam duration & Increasing the exam duration & 45 \\
\hline
\end{tabular}

Table 7 shows that participant teachers' arrangements for the learning environment for their students affected by disability are gathered in a single category called "adaptation in the physical layout of the classroom". In this category, most of the teachers $(f=37)$ stated that they made changes in the seating plan according to the type of disability of students. T21 stated his/her opinion as "I had a visually disabled student, I put him in the front row in every lesson."; T57 said his/her opinion as "My student had learning difficulties and attention deficit, I used to make him/her sit alone because he wouldn't be disturbed by his/her friend sitting next to him, he/she was already distracted easily...". On the other hand, 18 participating teachers stated that they did not allow any objects other than legally obligatory objects in the classroom, and that they adapted the physical layout of the classroom in the form of stimulus reduction. In this context, T3 expressed his/her opinion by saying, “... I cleaned the walls of the classroom. In other words, I did not leave anything hanging on the wall other than the board, Atatürk portrait, Turkish flag, seasons strip and the panel... " and T42 said, “... actually, I gathered everything unnecessary on the wall not only for disabled students but for all students to be distracted...". On the other hand, 3 participant teachers stated that they tried to increase the light by using more illuminators in the classroom for students affected by a visual disability. T2 explained the adaptation he made regarding the physical order of the classroom by saying “... I placed a floor lamp next to the desk where my visually disabled student is..."

Within the scope of the regulations for the teaching-learning process, 33 of the teachers clearly stated that they did not make any arrangements in teaching methods and techniques for their students with special needs, 11 teachers stated that they applied special teaching methods and techniques in their lessons. T1 expressed his/her opinion saying "There was a teaching method called social stories, we had a special education course during my student years. I use it a lot... ". In the category of organizing teaching materials, 34 teachers stated that made formal and content arrangements in the written materials they used in the teaching-learning process according to the type of disability, and changed the font size of the study texts and the paragraphs of the texts in a way that would not disturb the integrity of the meaning. T35 "I increase the font size of the text for my visually disabled student. Sometimes I make photocopies, sometimes I write the text on the computer and print it myself by increasing the font size... " and stated that he/she adapted the formal order of the written material. T41 said "... if the number of paragraphs of the text is too many, I reduce the paragraphs, so as not to disrupt the main idea... I rearrange the text in this way for my students with a visual disability, attention deficit and learning difficulties..." and stated that he/she arranged the content of the text. 18 participating teachers stated that they used visual materials to facilitate learning and to increase retention in learning according to their students' disability types and learning performances. T5 "I prepare flash cards in life studies lesson. ... I experienced that especially mentally disabled students learn better in this way... " and stated that students prefer visual materials according to the type of disability. 6 teachers stated that they preferred to use tactile materials in the teaching-learning process for their students with special needs. In this context, T11 said “... I used play dough a lot in mathematics lesson especially for my autistic student. Because they need a lot to learn by doing and living..." 2 teachers stated that they made use of real materials in the teaching-learning process according to the subject of the lesson and the opportunity to access the material.T8 said "The texture of the object is important for mentally and visually impaired students. For 
these students, I use real objects even when teaching fractions. For example, if I divide an apple, I use real leaves when teaching autumn. Of course, it is difficult to find real material for every subject. Of course, I cannot explain the digestive system in science with real materials..." and explained his/her opinion. 16 teachers stated that they made arrangements for students with special needs in the use of reinforcers, used fixed reinforcers for these students, they reward every correct answer given by the student. 11 teachers of inclusion students; stated that they used symbol reinforcer to increase their interest in the lesson and not to lose their sense of curiosity during the lesson. Some teachers' views are as follows: “... The more they answer the questions, the more I reward them. Candy, chocolate, sometimes money... " (T49); “... I give a smiley or a star. I don't give a direct reward. I say to them-If you collect two or three smiling faces and stars in the lesson, I have a surprise for you at the end of the lesson. The student is looking forward to the end of the lesson..." (T24).

Participant teachers stated that they mostly didn't use a specially developed measurement-evaluation tool in the measurement -evaluation process for their students with special needs, and they evaluated students according to their performance in the classroom. They stated that if a measurement -assessment tool is to be used in determining success; they evaluate the whole class with the same tool and give only additional time to students with special needs. Some teachers' views are as follows: “... Yes, I apply the same tests to students with special needs with the others, but I keep the time longer...” (T6); “... I don't do many exams, I usually look at school attendance, observe class participation, and give an average grade accordingly. If I am going to give an exam to them, it is as simple as possible. Frankly, I aim to make these children pass a class..." (Ö14).

In Table 8, the answers are given by the teachers to the question "Do you think every student can learn?" are included.

Table 8. Teachers 'views on students' ability to learn and the factors affecting learning

\begin{tabular}{cccc}
\hline Opinions & f & Factors affecting learning & f \\
\hline Every student can learn & 7 & Physical conditions & 3 \\
\hline & & Developmental features & 38 \\
& & Motivation & 24 \\
Every student cannot learn & 51 & Sense of responsibility & 21 \\
& & Parental support & 16 \\
& & Physical conditions & 11 \\
& & Social environment & 8 \\
& & Parents' education level & 5 \\
& Professional competency of the teacher & 2 \\
\hline
\end{tabular}

According to Table 8 , most of the teachers ( $\mathrm{f}=51)$ think that not every student can learn. In this context, 38 teachers stated that developmental characteristics affect learning, and some types of disability individuals have prevented learning. Some teacher opinions are as follows: "No, not every student can learn, dyscalculia is common, although not known. I could not teach this student to multiplication in four years... "(T13); "I think that not every student will be able to learn if the necessary opportunities are not provided, if the student does not have a request, and if the parents do not fulfil their part. But it is difficult to achieve this integrity... "(T5).

\section{Conclusion, Discussion and Recommendations}

This research determined that participant teachers' professional competencies regarding inclusive education are generally at the level of "I am competent". Reasons for obtaining such a result can be revising the teacher training bachelor programs in Turkey in 2006 by adding "special education" courses to all programs updated until today. Lancaster \& Bain (2010), in their study with Australian teacher candidates, reported that the inclusive education course given in teacher training is a predictor for high perceived professional competency. In Turkey, the presence of these students with special needs in each class by increasing their number, directing teachers to meet their professional development needs and also opening in-service training programs for special education and inclusion by the MNE may also have affected the perceptions of professional competency of participating teachers. Hastings \& Brown (2002) found in their study that special education teachers with low professional competency could not properly manage the undesirable behaviours of students with special needs. Hence, teachers with high professional competency in inclusive education are an essential component of creating a successful inclusive education classroom. In the literature, in parallel with the results of this research, there are research findings that indicate that the professional competency levels of teachers (Savolainen, Engelbrecht, Nel, \& Malinen, 2012; Tasnubaa \& 
Tsokova, 2015; Toy \& Duru, 2016) and teacher candidates (Ahmmed, Sharma, \& Deppeler, 2012; Hecht, Aiello, Pace, \& Sibilio, 2017; Özokçu, 2018) regarding inclusive education are high.

In this study, the scale DA sub-dimension, which includes information about the identification of students with special needs and the evaluation of their development processes, was determined as the dimension in which teachers' professional competency levels for inclusive education were the lowest compared to the other scale sub-dimensions. Similarly, Aydoğdu et al. (2016) and Battal (2007) found that teachers had a lack of knowledge about identifying students with special needs. It is important to carefully examine early diagnosis, intervention and development processes so that the capacities of students with special needs can be recognized and developed (Lerner, Lowenthal, \& Egan, 2003). Early diagnosis and intervention lead up to the next learning process, enabling children at risk to have positive experiences in their future academic lives and have various opportunities to develop their current potential (Steele, 2004). The fact that the teachers participating in this study stated that students with special needs do not have a high level of professional competency perception towards the diagnosis and evaluation process may cause these children to not benefit from the education they will receive at the desired level in the future.

The TMT sub-dimension of the scale, which includes information about the competencies of using teaching methods and techniques used in the teaching-learning process for students with special needs, was determined as the sub-dimension of the scale that the professional competencies of the participating teachers were the highest. It should be emphasized here that, in general, participant teachers have high professional competency in teaching methods and techniques used for normally developing students. Indeed, the findings obtained from the qualitative data of the research confirm this interpretation. While only 11 of the 58 teachers participating in the interview process stated that they applied some teaching methods and techniques used in special education in their lessons, 33 teachers clearly stated that they did not make any arrangements in the teaching methods and techniques for their students affected by disability. Each field has its specific teaching methods. Using appropriate, accurate and effective methods will make it easier for students to reach their learning outcomes. MNE (2008) stated that although general and special education are similar in terms of teaching methods and techniques, regulations should be made on teaching methods and techniques according to the type of disability, educational performance and needs of students who continue their education with inclusive education practices. In some studies, it has been determined that teachers need special education methods for their students with special needs in their teaching-learning processes (Aktan, 2020; Everling, 2013). However, this result obtained from this study can be interpreted as participant teachers do not need the use of special teaching methods and techniques for inclusive students in their classrooms.

As a result of this research, it was determined that the professional competencies of the participant teachers regarding inclusive education do not differ significantly according to gender and professional seniority degrees. The reason for this situation may be that teachers do similar practices in the classroom for their students who are affected by disability. When the analysis of qualitative data is examined, most of the teachers in their teaching planning for these students; It has been determined that they consider the readiness levels of the students, adapt the activity to be applied in the course according to the disability type of their students, and design acquisitions/activities that will improve disabled students life skills. It has been determined that the perceptions of participating teachers towards the arrangement of the learning environment for their students who are affected by disability ,in general, are limited by the physical space of the classroom and the seating arrangement of the students. Although there are studies in which the physical space of the classroom affects learning, instructional arrangements, and teachers 'and students' attitudes towards school (Denton, 1992), also the temperature of the classroom, ventilation, light condition, sound, the height of the board, tables, desks in the classroom, classroom rules, classroom climate, time and arrangement of homework are within the scope of learning environment regulations (Uslu \& Çoruhlu, 2012). However, this situation was neglected by most of the participating teachers. Teachers generally stated that they do not use special teaching methods and techniques for their students with special needs, and they mostly use written materials in their teaching materials. Within the scope of the regulations for the measurement-evaluation process, the majority of the teachers stated that instead of determining the academic achievement using measurement-evaluation tools, they consider the performance of the student in the classroom and evaluate the student in line to pass the class. When looking at these data, it is seen that teachers have similar levels of competency to develop and apply measurement tools that will increase the engagement of students with special needs in their classes, facilitate their learning processes, and determine their real achievement levels, regardless of their gender and seniority. In various studies in the literature, similar results are encountered (Kuyini, Desai, \& Sharma, 2018; Özokçu, 2018).

As a result of the study, it was determined that teachers' professional competencies regarding inclusive education 
according to the total number of students affected by disability in their classrooms differed significantly in the $\mathrm{FE} / \mathrm{C}$ factor of the scale. The professional competency levels of teachers with a total of 1-5 students affected by disability in their class are higher than the competencies of teachers with a total of 6-10 and 16 or more students in their class. The reason for this result may be that the finding may vary depending on the type of disability of students with special needs, their academic achievement level, their families' openness to cooperation with the school, and teachers' openness to collaboration with their colleagues.

When the data of the research are evaluated as a whole, it can be said that the participant teachers' professional competencies regarding inclusive are high in terms of their "knowledge level" but low in terms of their "practice level". It was determined that teachers generally consider their students affected by disability as a part of the classroom, they know what to do at the theoretical level for these students, but they cannot reflect this knowledge to the application at the desired level, they cannot differentiate the learning environment for these students following the purpose of special education, and they cannot benefit from special teaching methods. Obtaining similar results in their research, Salend and Garrick-Duhaney (1999) emphasized that it is important to support teachers in terms of cooperation for teaching and physical resources, using different strategies, preparing and implementing time and teaching plans, and evaluation. The reason for such a conclusion from the research may be that the majority of teachers believe that not every student can learn. Qualitative data show that the participating teachers generally have the belief that each student - especially though it varies according to the type of disability - that the vast majority of students with special needs cannot learn. This idea means that all special education studies that have been carried out since the early 1800's practices of modern special education lose their meaning. Because special education is based on the understanding that every individual can learn, that the strengths of learners should be taken as a basis, that different learners are not a deficiency in the classroom, but a richness (Ohio Coalition for the Education of Children with Disabilities, 2000). The student's disability is a small impact that affects his learning. While the disability diagnosis gives information about the general characteristics of the student, it does not give much information about educational needs. Because students with the same diagnosis uniquely experience their disabilities and differ in terms of personality, temperament, skills, interests and capacities (Shaddock, Giorcelli, \& Smith, 2007). Therefore each student can learn in line with their capacity and educational needs. However, there is no doubt that learners need guidance in this process, and teachers will be able to provide them with the best guidance. For this reason, the work should be started from teacher training, teachers should be given the knowledge that education can be everywhere and that each individual has learning potential through "practical" activities, and the perception that "every student can learn when necessary and appropriate learning opportunities are provided" should be placed on teachers.

Recommendations based on the results obtained in the research:

- It should be questioned whether teachers need information about the diagnosis and evaluation of students with special needs, and if there are, trainings should be organized to meet these needs.

- It should be questioned which teaching methods and techniques teachers generally use in inclusive education, whether they need special teaching methods and techniques, and if there is a need for knowledge and skills on this subject, educational studies should be conducted to meet the teachers' needs.

- In the future, researches can be conducted to examine the effect of the relationship between the families of students with special needs and their teachers on the professional competencies of teachers for inclusive education.

- Courses such as "education at home, education at hospital, natural education" can be added to teacher training undergraduate programs. In-service training programs for these courses can also be organized for teachers on duty. The "application" dimension can be added to the existing special education programs in existing undergraduate programs, Candidate teachers can be provided with the opportunity to work with special needs students and special education specialists in special education schools and to see students and classroom practices.

\section{References}

Ahmmed, M., Sharma, U., \& Deppeler, J. (2012). Variables affecting teachers' attitudes towards inclusive education in Bangladesh. Journal of Research in Special Educational Needs, 12(3), 132-140. https://doi.org/10.1111/j.1471-3802.2011.01226.x

Ahsan, T. M., Sharma, U., \& Deppeler, M. J. (2012). Exploring pre-service teachers' perceived teaching-efficacy, attitudes and concerns about inclusive education in Bangladesh. International Journal of Whole Schooling, 8(2), 1-20. Retrieved from https://files.eric.ed.gov/fulltext/EJ975715.pdf 
Aktan, O. (2020). Determination of educational needs of teachers regarding the education of inclusive students with learning disability. International Journal of Contemporary Educational Research, 7(1), 149-164. https://doi.org/10.33200/ijcer.638362

Anderson, J. C., \& Gerbing, D. W. (1984). The effect of sampling error on convergence, improper solutions, and goodness-of-fit indices for maximum likelihood confirmatory factor analysis. Psychometrika, 49, 155-173. https://doi.org/10.1007/BF02294170

Andrews, J., \& Lupart, J. L. (2000). The inclusive classroom: Educating exceptional children. Scarborough, Ontario Canada: Nelson.

Aydoğdu, F., Akalın, A., Polat, B., İrice, N. \& Akpınar, M. (2016). Analzying the views of pre-school teachers upon the identification of special-need children. Manas Journal of Social Studies, 5(4), 14-21. Retrieved from https://dergipark.org.tr/tr/pub/mjss/issue/40507/485469

Battal, İ. (2007). The evaluation of the sufficiency of the class and branch teachers on fusion education (sample of Usak city) (Unpublished master thesis). Afyonkarahisar Kocatepe Ünivercity, Department of Elemantary Education, Afyonkarahisar, Turkey.

Bollen, K. A. (1989). Structural equations with latent variables. New York: Wiley. https://doi.org/10.1002/9781118619179

Denton, P. (1992). Seating arrangements for better classroom management. Adventist Education, 54(5), 29-32. Retrieved from http://circle.adventist.org/files/jae/en/jae199254052904.pdf

Diken, İ. H., \& Batu, S. (2013). Kaynaştırmaya giriş. In İ. H. Diken (Ed.), İlköğretimde kaynaştırma (pp. 2-23). Ankara: Pegem Akademi. https://doi.org/10.14527/9786053640974.01

Everling, K. M. (2013). Special education students in a general education classroom: Texas educators' perspectives. Journal of Education and Human Development, 2(2), 1-14. Retrieved from http://jehdnet.com/journals/jehd/Vol_2_No_2_December_2013/1.pdf

Hastings, R., \& Brown, T. (2002). Behavioral knowledge, causal beliefs and self-efficacy aspredictors of special educators' emotional reactions to challenging behaviors. Journal of Intellectual Disability Research, 46, 144-150. https://doi.org/10.1046/j.1365-2788.2002.00378.x

Hecht, P., Aiello, P., Pace, M. E., \& Sibilio, M. (2017). Attitudes and teacher efficacy among Italian and Austrian teachers: A comparative study. Formazione and Insegnamento, 15(1), 269-282. Retrieved from http://webcache.googleusercontent.com/search?q=cache:14IHqakETEcJ:ojs.pensamultimedia.it/index.php/si ref/article/viewFile/2179/1988+\&cd=4\&hl=tr\&ct=clnk\&gl=tr

Jöreskog, K. G., \& Sörbom, D. (1993). LISREL 8: Structural equation modeling with the SIMPLIS command language. New Jersey: Lawrence Erlbaum.

Karaca, A., \& Sarı, H. (2018). Kaynaştırma eğitimi programının öğretmenlerin kaynaştırma uygulamalarındaki mesleki yeterliliklerine etkisi (Unpublished master thesis). Necmettin Erbakan Univercity, Institute of Education Sciences, Konya, Turkey.

Kristiana, F. I., \& Hendriani, W. (2018). Teaching efficacy in inclusive education (ie) in Indonesia and other Asia, developing countries: A Systematic review. Journal of Education and Learning, 12(2), 166-171. https://doi.org/10.11591/edulearn.v12i2.7150

Kuyini, A. B., Desai, I., \& Sharma, U. (2018). Teachers' self-efficacy beliefs, attitudes and concerns about implementing inclusive education in Ghana. International Journal of Inclusive Education, 24(1), 1-18. https://doi.org/10.1080/13603116.2018.1544298

Lancaster, J., \& Bain, A. (2010). The design of pre-service inclusive education courses and their effects on self-efficacy: A comparative study. Asia-Pacific Journal of Teacher Education, 38(2), 117-128. https://doi.org/10.1080/13598661003678950

Lee, M. L. F., Tracey, D., Barker, K., Fan, M. C. J., \& Yeung, S. A. (2014). What predicts teachers' acceptance of students with special educational needs in kindergarten? Australian Journal of Educational \& Developmental Psychology, 14, 60-70. Retrieved from: https://files.eric.ed.gov/fulltext/EJ1041676.pdf

Lerner, J. W., Lowenthal, B., \& Egan, R. W. (2003). Preschool children with special needs. Boston: Allyn and Bacon.

Loreman, T., Sharma, U., \& Forlin, C. (2013). Do pre-service teachers feel ready to teach in inclusive classrooms? 
A four country study of teaching self efficacy. Australian Journal of Teacher Education, 38, 27-44. https://doi.org/10.14221/ajte.2013v38n1.10

Mag, G. A., Sinfield, S., \& Burns, T. (2017). The benefits of inclusive education: new challenges for university teachers. MATEC Web of Conferences 121. https://doi.org/10.1051/matecconf/201712112011

Marsh, H. W., Balla, J. R., \& McDonald, R. P. (1988). Goodness-of-fit indexes in confirmatory factor analysis: The effect of sample size. Psychological Bulletin, 103, 391-410. https://doi.org/10.1037/0033-2909.103.3.391

MEB. (2008). Kaynaştırma yoluyla eğitim uygulamalart. Retrieved from https://orgm.meb.gov.tr/meb_iys_dosyalar/2015_07/24014806_kaynastirma1.sra.pdf

MEB. (2010). Okullarımızda neden, nasıl, niçin kaynaştırma. Retrieved from http://orgm.meb.gov.tr/alt_sayfalar/yayimlar/kaynastirma/kaynastirma.pdf

MEB. (2017). Öğretmenlik mesleği genel yeterlikleri. Retrieved from https://oygm.meb.gov.tr/www/ogretmenlik-meslegi-genel-yeterlikleri/icerik/39

Miles, M, B., \& Huberman, A. M. (1994). Qualitative data analysis: An expanded Sourcebook. Thousand Oaks, CA: Sage.

Ministry of Family, Labour and Social Services. (2020). Engelli ve yaşl istatistik bülteni 2020-Mart. Retrieved from https://www.ailevecalisma.gov.tr/media/42250/istatistik-bulteni-2020-mart.pdf

Mintz, J. (2019). A comparative study of the impact of enhanced input on inclusion at pre-service and induction phases on the self-efficacy of beginning teachers to work effectively with children with special educational needs. British Educational Research Journal, 45(2), 254-274. https://doi.org/10.1002/berj.3486

Moeller, A. J., \& Ishii-Jordan, S. (1996). Teacher efficacy: A model for teacher development and inclusion. Journal of Behavioral Education, 6(3), 293-310. https://doi.org/10.1007/BF02110132

Nina, F. C. K., Silva, C. S. S., \& Pontes, R. A. F. (2020). Transcultural adaptation of The Teacher Efficacy for Inclusive Practices (TEIP): Brazilian version. Ciencias Psicológicas January, 14(1), e-2175. https://doi.org/10.22235/cp.v14i1.2175

OECD. (1999). Inclusive education at work: Including students with disabilities in mainstream schools. Paris: OECD publishing.

Ohio Coalition for the Education of Children with Disabilities. (2000). Students with disabilities \& the general education curriculum. Retrieved from https://www.govinfo.gov/content/pkg/ERIC-ED466857/pdf/ERICED466857.pdf

Özokçu, O. (2018). Investigating preschool teachers' self-efficacy in inclusion practices in Turkey. International Education Studies, 11(9), 79-89. https://doi.org/10.5539/ies.v11n9p79

Paneque, O. M., \& Barbetta, P. M. (2006). A study of teacher efficacy of special education teachers of English language learners with disabilities. Bilingual Research Journal, 30(1), 171-193. https://doi.org/10.1080/15235882.2006.10162871

Salend, S. J., \& Garrick-Duhaney, L. M. (1999). The Impact of inclusion on students with and without disabilities and their educators. Remedial and Special Education, 20(2), 114-126. https://doi.org/10.1177/074193259902000209

Savolainen, H., Engelbrecht, P., Nel, M., \& Malinen, O.-P. (2012) Understanding teachers' attitudes and self-efficacy in inclusive education: Implications for preservice and in-service teacher education. European Journal of Special Needs Education, 27(1), 51-68. https://doi.org/10.1080/08856257.2011.613603

Shaddock, A., Giorcelli, L., \& Smith, S. (2007). Students with disabilities in mainstream classrooms A resource for teachers. Canberra: Australian Government Department of Education.

Sharma, U., Forlin, C., \& Loreman, T. (2007). What concerns pre-service teachers about inclusive education: An international viewpoint? KEDI Journal of Educational Policy, 4(2), 95-114. Retrieved from https://www.proquest.com/openview/632c10dd40b35bc90468c464eaa9750a/1?pq-origsite $=$ gscholar\&cbl=9 46348

Steele, M. M. (2004). Making the case for early identification and intervention for young children at risk for learning disabilities. Early Childhood Education Journal, 32(2), 75-79. https://doi.org/10.1007/s10643-004-1072-x 
Stromstad, M., Nes, K., \& Skogen, K. (2004). What is inclusion? Evaluation of reform 97. Oplandske Bokforlag.

Tasnubaa, T., \& Tsokova D. (2015). BRAC primary school teachers' teaching-efficacy, attitude, sentiment and concern towards inclusion of children with disabilities in regular classrooms in Bangladesh. Asian Journal of Inclusive Education, 3(1), 53-78. Retrieved from http://ajie-bd.net/old/pdf/tasnuba_sokova_final.pdf

Toy, N. S., \& Duru, S. (2016). The comparison of self-efficacy and inclusive education beliefs of primary school teachers. Ege Journal of Education, 17(1), 146-173. https://doi.org/10.12984/eed.00332

United Nations. (2007). Convention on the rights of persons with disabilities. Retrieved from https://www.un.org/development/desa/disabilities/convention-on-the-rights-of-persons-with-disabilities.htm 1

Uslu, Y., \& Çoruhlu, E. (2012). Kaynaştırma eğitiminde öğretimsel düzenlemeler. Ankara: Epamat.

WHO. (2011). World report on disability. Retrieved from https://www.who.int/publications/i/item/9789241564182

\section{Copyrights}

Copyright for this article is retained by the author(s), with first publication rights granted to the journal.

This is an open-access article distributed under the terms and conditions of the Creative Commons Attribution license (http://creativecommons.org/licenses/by/4.0/). 